\title{
Short-Chain Fatty Acids and Their Association with Signalling Pathways in Inflammation, Glucose and Lipid Metabolism
}

\author{
Jin He ${ }^{1,2,+}$, , Peiwen Zhang ${ }^{1,2,+}$, Linyuan Shen ${ }^{1,2} \mathbb{D}^{\text {, Lili Niu }}{ }^{1,2}$, Ya Tan ${ }^{1,2,3}$, Lei Chen ${ }^{1,2}$, \\ Ye Zhao ${ }^{1,2}$, Lin Bai ${ }^{1,2}$, Xiaoxia Hao ${ }^{1,2}$, Xuewei Li ${ }^{1,2}$, Shunhua Zhang ${ }^{1,2, *}$ and Li Zhu ${ }^{1,2, *}$ \\ 1 College of Animal Science and Technology, Sichuan Agricultural University, Chengdu 611130, China; \\ hejin19960812@163.com (J.H.); sicau_zhangpeiwen@163.com (P.Z.); shenlinyuan0815@163.com (L.S.); \\ dky9829@126.com (L.N.); tanya@stu.sicau.edu.cn (Y.T.); chenlei815918@sicau.edu.cn (L.C.); \\ zhye3@foxmail.com (Y.Z.); blin16@126.com (L.B.); xiaoxia6363@126.com (X.H.); xuewei.li@sicau.edu.cn (X.L.) \\ 2 Farm Animal Genetic Resource Exploration and Innovation Key Laboratory of Sichuan Province, \\ Sichuan Agricultural University, Chengdu 611130, China \\ 3 Institute of Animal Husbandry and Veterinary, Guizhou Academy of Agricultural Science, \\ Guiyang 550005, China \\ * Correspondence: zhangsh1919@163.com (S.Z.); zhuli7508@163.com (L.Z.); \\ Tel.: +86-28-8629-1133 (S.Z. \& L.Z.) \\ + These authors contributed equally to this work.
}

Received: 11 July 2020; Accepted: 27 August 2020; Published: 2 September 2020 updates

\begin{abstract}
Short-chain fatty acids (SCFAs), particularly acetate, propionate and butyrate, are mainly produced by anaerobic fermentation of gut microbes. SCFAs play an important role in regulating energy metabolism and energy supply, as well as maintaining the homeostasis of the intestinal environment. In recent years, many studies have shown that SCFAs demonstrate physiologically beneficial effects, and the signalling pathways related to SCFA production, absorption, metabolism, and intestinal effects have been discovered. Two major signalling pathways concerning SCFAs, G-protein-coupled receptors (GPRCs) and histone deacetylases (HDACs), are well recognized. In this review, we summarize the recent advances concerning the biological properties of SCFAs and the signalling pathways in inflammation and glucose and lipid metabolism.
\end{abstract}

Keywords: short-chain fatty acids; inflammation; glycose and lipid metabolism; signalling pathways

\section{Introduction}

Short-chain fatty acids (SCFAs), also called volatile fatty acids, are organic linear carboxylic acids with fewer than six carbons, including acetic acid, propionic acid, butyric acid, and valeric acid. Among them, acetate (C2), propionate (C3), and butyrate (C4) are the most abundant $(\geq 95 \%)$ [1], and the $C 2, C 3$, and $\mathrm{C} 4$ are in an approximate molar ratio of 60:20:20, respectively [2,3]. Except for a small portion of SCFAs obtained directly from food, most are produced by intestinal microbial anaerobic fermentation. Furthermore, around 500-600 mmol of SCFAs are produced in the intestinal tract per day, depending on the diet, type and number of microbiomes, and residence time in the intestinal tract $[4,5]$.

Dietary fibre is the main food component that affects the production of SCFAs, which are mainly derived from plant foods. Humans lack enzymes that breakdown dietary fibre. Therefore, dietary fibre passes through the upper digestive tract largely undigested and is fermented in the caecum and large intestine by anaerobic microorganisms. A key mechanism of metabolic regulation by the gut microbiota is the production of SCFAs. Different intestinal microbes will produce different amounts of SCFAs. Bacteroidetes (Gram negative) mainly produce acetate and propionate, whereas 
Firmicutes (Gram positive) use butyrate as the primary metabolic end product [5]. Human-derived Bifidobacterium breve UCC2003 and Bifidobacterium longum NCIMB 8809 use novel oligosaccharides to produce acetate [6], and Bifidobacterium animalis subsp. Lactis GCL2505 can also increase the production of acetate [7]. Although anaerobic fermentation of fibre by intestinal microorganisms is the largest source of SCFAs, SCFAs are also formed as products from peptide and amino acid fermentation (less than 1\%) [8,9]. Although diet and the microbiome are the main factors affecting the production of SCFAs, species evolution and colonic environment have important effects [10,11].

Colonocytes absorb SCFAs after they are produced mainly via $\mathrm{H}^{+}$-dependent or sodium-dependent monocarboxylate transporters [12]. After supplying colonocytes, the remaining SCFAs are transported through the blood to various parts of the body. These SCFAs can be used as substrates to synthesize sugars or lipids and can also be used as cytokines to regulate metabolism [13-16]. These results show that SCFAs are carried from the intestinal cavity into the blood vessels of the host and finally to organs as substrates or signalling molecules.

Additionally, a growing number of functions are attributed to SCFAs. For a long time, many studies have argued that dietary fibre and resistant starch have many benefits, such as reducing cholesterol levels and maintaining normal blood glucose levels [17-19], and these benefits of high-fibre diets are at least a part put down to SCFAs. When SCFAs are produced in the gut, many of them are used as energy sources. For humans, SCFAs provide approximately $10 \%$ of the daily calorie requirement [20]. SCFAs also improve gut health through several partial effects, including maintaining the integrity of the intestinal barrier, producing mucus, preventing inflammation and reducing the risk of colorectal cancer [21-25]. Furthermore, the effects on activating brown adipose tissue [26], regulating liver mitochondrial function [27], maintaining body energy homeostasis [28], controlling appetite [26] and sleep [29] are all related to SCFAs.

Among the many physiological functions of SCFAs, the regulation of inflammation and glucose and lipid metabolism, has concerned most researchers. SCFAs play a very important role in these physiological processes, but how do SCFAs work? This mini review aims to summarize the current knowledge concerning the biological properties of SCFAs and their signalling pathways in inflammation and glycose and lipid metabolism.

\section{G Protein-Coupled Receptors (GPCRs)}

G protein-coupled receptors (GPCRs), involving seven transmembrane domains, are the biggest receptor family in mammals and participate in regulating almost all cell and physiological functions in the body. GPCRs can bind chemicals in the extracellular environment, such as odourants, hormones, neurotransmitters, chemokines, sugars, lipids, and proteins. After being activated by a ligand, GPCRs can bind to four different heterotrimeric $G$ proteins $\left(G_{s}, G_{i} / o, G_{q} / 11\right.$ and $\left.G_{12} / 13\right)$, which can influence the activity of single or multiple effectors, such as second-messenger-producing enzymes or ion channels. Presently, GPR41 and GPR43 have been identified as the most important receptors of SCFAs in the GPCR family [30,31]. After the discovery of SCFA receptors, GPR41 was renamed free fatty acid receptor 3 (FFAR3) and GPR43 was renamed FFAR2. Different SCFAs and receptors have different affinities. Specifically, in humans, the affinity ranking of FFAR2 is $\mathrm{C} 2=\mathrm{C} 3>\mathrm{C} 4>\mathrm{C} 5=\mathrm{C} 1$ and that of FFAR 3 is $\mathrm{C} 3=\mathrm{C} 4=\mathrm{C} 5>\mathrm{C} 2>\mathrm{C} 1[32,33]$. Both FFAR2 and FFAR3 are associated with metabolic diseases, and they have become effective targets for the treatment of type 2 diabetes, asthma, cardiovascular disease, as well as metabolic syndrome.

FFAR2 is widely expressed in vivo. FFAR2 is present in pancreatic islet $\alpha$ and $\beta$ cells $[34,35]$ and intestinal enteroendocrine cells (I and L cells) (Table 1) [36,37]. FFAR2 expression has been identified along the entire gastrointestinal tract and white adipocytes [38,39]. Moreover, FFAR2 is present in monocytes, neutrophils, eosinophils, intestinal Treg cells and other immune cells [40-42]. An increasing number of studies have confirmed the function of FFAR2. Attilio et al. found that FFAR2 stimulates insulin secretion and reduces apoptosis in mouse and human islets in vitro [43]. Kendle et al. found that FFAR2 gene knockout mice showed significant aggravation in colitis, arthritis and asthma [40]. 
FFAR2 significantly inhibits the lipolysis of primary human fat cells and stimulates the secretion of Glucagon-Like Peptide-1 (GLP-1) by mouse enterocrine tumour (STC-1) cells [44]. However, in another study, FFAR2 inhibited intestinal transport, intestinal function, and food intake through the peptide YY (PYY, an enteroendocrine hormone that reduces gut motility) pathway, along with limiting the function of GLP-1 [45]. Thus, although SCFA may alter the function of some proteins, further analysis is needed to determine the specific role of SCFA in different situations.

Additionally, SCFAs can activate Gi/o protein through FFAR2 and inhibit adenylate cyclase, reducing the production of cAMP from ATP [46]. Activation of FFAR2 can phosphorylate ERK1/2, activate mitogen-activated protein kinase (MAPK) and increase $\mathrm{Ca}^{2+}$ concentration [47]. C3 can promote the release of anti-inflammatory interleukin 10 (IL-10) from Treg cells, a process that occurs in a manner specific to FFAR2 [42]. Moreover, SCFAs can inhibit the expression of IL-6, IL-1 $\beta$ and tumour necrosis factor $\alpha(\mathrm{TNF} \alpha)$ to exert anti-inflammatory effects by FFAR2 [48-50].

In addition to intestinal enteroendocrine cells, FFAR3 was found in K cells, enteric neurons and sympathetic ganglia (Table 1) [51,52]. Consistent with FFAR2 function, FFAR3 also plays important roles in inflammation. C3 can inhibit the expression of IL-4, IL-5, and IL-17A through FFAR3, and C4 can inhibit the expression of induced nitric oxide synthase (iNOS), TNF $\alpha$, IL-6, and monocyte chemoattractant protein-1 (MCP-1) [53-55]. Both FFAR2 and FFAR3 can be combined with $\mathrm{G}_{\mathrm{i} / \mathrm{o}}$ receptor [31,56,57]. But FFAR3 can only function through $\mathrm{G}_{\mathrm{i} / \mathrm{o}}$ receptor, while FFAR2 is pleiotropic, and it can also perform its functions through the $\mathrm{G}_{\mathrm{q} / 11}$ pathway [30].

Certainly, FFAR3 also has different functions from FFAR2. FFAR3 is mainly expressed in neurons with a vasoconstrictor phenotype [58]. Many studies have investigated the role of FFAR3 in vasoconstriction. For example, C3 causes protective effects on allergic airway inflammation through FFAR3 [59]. FFAR3 activation induces vasodilation and lowers systemic blood pressure in vascular smooth muscle cells $[60,61]$. In human airway smooth muscle (ASM), FFAR3 promotes ASM contraction by reducing cAMP and increasing intracellular $\mathrm{Ca}^{2+}$ [62]. FFAR3 does not only play a role in vasoconstriction. Ørgaard et al. found that SCFA treatment did not affect the secretion of glucagon in vitro, and the inhibitory effects on insulin secretion were weak but induced a strong increase in somatostatin secretion [63]. In another study, FFAR3 signalling mediated glucose-stimulated insulin secretion through the Gi/o-sensitive pathway, and FFAR3 signalling negatively mediates insulin secretion [64]. Moreover, exogenous supplementation of SCFAs can reduce liver fat content and improve liver metabolism by inhibiting the expression of lipid synthesis genes in FFAR3-deficient mice liver but not FFAR2-deficient [65].

Table 1. Short-chain fatty acids (SCFAs) receptor and its main expression site.

\begin{tabular}{|c|c|c|c|c|c|}
\hline SCFAs Receptors & Alternative Names & G-Protein Coupling & Affinity & Expression & References \\
\hline FFAR2 & FFA2; GPR43 & $\mathrm{Gq} / \mathrm{G}_{11} ; \mathrm{Gi}$ & $\mathrm{C} 2=\mathrm{C} 3>\mathrm{C} 4>\mathrm{C} 5=\mathrm{C} 1$ & $\begin{array}{l}\text { white adipocytes, immune cells, islet } \alpha \text { and } \\
\beta \text { cells, intestinal enteroendocrine cells }\end{array}$ & [34-42] \\
\hline FFAR3 & FFA3; GPR41 & $\mathrm{Gi}$ & $\mathrm{C} 3=\mathrm{C} 4=\mathrm{C} 5>\mathrm{C} 2>\mathrm{C} 1$ & $\begin{array}{l}\text { immune cells, enteric neurons and } \\
\text { sympathetic ganglia, intestinal } \\
\text { enteroendocrine cells, islet } \alpha \text { and } \beta \text { cells, }\end{array}$ & {$[34-37,51,52]$} \\
\hline GPR109A & HCA2 & $\mathrm{Gi}$ & $\mathrm{C} 4$, niacin & $\begin{array}{l}\text { Macrophages, immune cells, Adipocytes, } \beta \\
\text { cells microvascular endothelial cells, } \\
\text { microglial cells }\end{array}$ & [66-73] \\
\hline
\end{tabular}

In initial reports, GPR109A was found in the intestinal tract, partial immune cells, and adipocytes (Table 1) [66,67]. Interestingly, these researchers found that GPR109A is not activated by SCFAs but niacin, a famous lipid-lowering substances [68]. Almost simultaneously, the receptor GPR109b, which is homologous to the GPR109A sequence, was also found, but it had a lower affinity for niacin [69]. Over time, researchers found that SCFAs also activate GPR109A. Unlike FFAR2 and FFAR3, GPR109A is activated by longer SCFAs, mainly C4 [70]. GPR109A is also widely expressed in vivo. GPR109A was detected in the bone marrow, lymph node, prostate and spleen by qRT-PCR and plays an important role in these organs [71]. Similarly, GPR109A is expressed in both mouse and human islet $\beta$ cells, although very rarely. And GPR109A, also expressed in breast tissue, inhibits the progression of breast tumours 
by promoting apoptosis [72]. In addition, the intestinal epithelial cells are also the site of GPR109A expression [67]. Moreover, GPR109A is also expressed in the brain, especially at the ventrolateral end of the rostral medulla, and is related to blood pressure regulation [73]. Li et al. found that GPR109A functions as an anti-inflammatory effector by inhibiting the Akt/mTOR signalling pathway in MIN6 pancreatic $\beta$ cells [74].

The GPR109A receptor has many functions. For example, Kaye et al. found that SCFAs can exert cardiovascular protection through GPR43/GPR109A receptors and can affect DNA methylation to increase the number of Treg cells [75]. Additionally, GPR109A inhibits insulin secretion and is downregulated in pancreatic beta cells of type 2 diabetes [76]. Activation of niacin receptor HCA2 can suppress macrophage migration induced by chemical kinases [77]. These effects were mainly caused by the effect of activated GPR109A on the intracellular CAMP content. In islets, GPR109A activation reduces insulin secretion. Interestingly, GPR109A expression was significantly reduced in the islets of $\mathrm{db} / \mathrm{db}$ mice in the same study [76]. In adipose tissue, lipase activity, plasma triglyceride levels and free fatty acid levels were reduced following GPR109A activation. Moreover, in the gut, GPR109A was used as a nutrient signal by enhancing the expression of MCT-1 through C4 treatment. GPR109A KO mice were more susceptible to dss-induced colitis than the control group, and GPR109A was found to be downregulated in human colon cancer cell lines (along with mouse models of colon cancer) $[42,67,78]$. In summary, GPR109A is expressed in many organs and cells and is beneficial to metabolism.

\section{Histone Deacetylases (HDACs)}

Histone deacetylase (HDAC) is a type of protease that plays an important role in chromosome structure modification and gene expression regulation. In general, histone acetylation is conducive to the dissociation of DNA from histone octamers and the relaxation of nucleosome structure, causing various transcription factors and synergistic transcription factors to specifically bind to DNA binding sites and activate gene transcription. Within the nucleus, histone acetylation and histone deacetylation are in dynamic equilibrium and are jointly regulated by histone acetyltransferase (HAT) and histone deacetylase (HDAC). HAT transfers the acetyl group of acetyl-CoA to a specific lysine residue at the amino terminus of histones. HDAC deacetylates histones, making them bind to negatively charged DNA, curling chromatin, and inhibiting gene transcription.

SCFAs are natural inhibitors of HDACs. The inhibitory effect of SCFAs on HDACs depends on the SCFA concentration, and the inhibitory effect of a high SCFA concentration is more obvious. Among all SCFAs, butyrate is the most potent inhibitor of HDAC activity. Studies dating back to 1978 have shown that SCFAs can increase histone acetylation. Sealy and Chalkley found that treatment of hepatoma tissue with acetate, propionate, or butyrate leads to a global increase in histone acetylation [79]. In the same year, Boffa et al. found that butyrate had stronger HDAC inhibitory activity than propionate in HeLa cells and colon cancer cell lines [80]. Similarly, in the follow-up study, Waldecker et al. found that HDAC was inhibited at concentrations $\geq 10 \mathrm{mM}$ in most SCFAs tests, except for acetate, while butyrate showed significant inhibition at $2 \mathrm{mM}$ and almost $40 \%$ inhibition at $1 \mathrm{mM}$; butyrate also showed better inhibition in nuclear extracts [81]. However, in both studies and some other studies, acetate had little or no effect on HDAC. However, this lack of effect on HDACs by acetate may be tissue dependent since others have shown that acetate can inhibit HDACs. In 2011, Soliman and Rosenberger found that exogenous supplementation significantly reduced HDAC levels in rat brain and liver without affecting HAT levels [82]. On the other hand, Bulusu et al. found that acetate can be converted to acetyl-coa directly providing the acetyl group for histone acetylation but in a very small proportion [83]. The role of acetate in histone acetylation is complex because it can supply acetyl units for HAT and act as an HDAC inhibitor.

Although the mechanism by which SCFA inhibits HDACs is still unclear, SCFAs may directly act on HDACs through transporters into the cell, or may indirectly act on HDACs through GPCR activation. For example, $\mathrm{C} 4$ inhibits the production of nitric oxide and inflammatory cytokines such as IL-6 and IL-12 induced by lipopolysaccharide, and the way does not depend on GPCRs, presumably 
by inhibiting HDAC [84]. In this study, the author believes that C4 acts directly on HDAC. SCFAs can enter cells through the transporter sodium coupled to monocarboxylic acid transporter 1 (SMCT-1) without passing through the membrane receptor, occupying the active site of HDACs and causing inhibition [85]. In another report, Wu et al. found that activation of GPR41 can inhibit histone acetylation in Chinese hamster ovary cell lines by inhibiting HDAC [86]. Additionally, GPR41, GPR43 and GPR109 may be involved in SCFA-mediated HDAC inhibition. How SCFAs directly or indirectly inhibit HDAC activity remains unclear, and extensive research is needed to answer these questions.

Generally, HDAC inhibition promotes chromatin acetylation and target gene transcription, thereby affecting cell function, although it is not clear how cell and gene selectivity is achieved. Additionally, HDAC inhibition has numerous downstream consequences. Our understanding of how SCFAs inhibits HDAC is still in its preliminary stages and will require us to study and explain this question in the future.

\section{SCFAs and Inflammation}

LPS (lipopolysaccharide), which comprises lipids and polysaccharides, is a major component of the cell wall of Gram-negative bacteria. As a classical pattern-recognition molecule, LPS plays an important role in the dynamic process of natural immunity. The LPS levels are one of the diagnostic markers in inflammatory diseases [87]. After LPS falls off the bacterial cell wall, it is detected by lipopolysaccharide binding protein (LBP) in the serum and applied to the TLR on macrophages or neutral cells. These cells then secrete pro-inflammatory factors such as TNF, IL-1 $\beta$ and IL-6, leading to an inflammatory response $[88,89]$. The two major inflammation-related signalling pathways in cells, NF-кB and MAPK pathways, are activated after TLR activation. NF- $\mathrm{KB}$ belongs to a family of nuclear transcription factors comprising p50, p52, REL, REL-a, and REL-B, and it is the primary response to harmful cellular stimuli. Currently, several downstream mediators have been identified to activate the NF-KB pathway: TNF- $\alpha$, IL-1, IL-2, IL-6, IL-8, IL-12, iNOS, COX2, chemokines, adhesion molecules, and colony stimulating factors [90-93]. The MAPK signalling pathway is involved in the regulation of various key functions in the body and plays an important role in cell proliferation, differentiation and apoptosis. Studies have shown that inhibition of the MAPK pathway in the lung can abolish the LPS-induced TNF production, inhibit the recruitment of neutrophils in pulmonary bronchi, and completely disable the endotoxin-induced inflammatory response [94]. Presently, three downstream MAPK pathways have been identified: ERK1/2, JNK/ASPK and P38 MAPK. Activation of the LPS-induced ERK pathway results in the secretion of inflammatory cytokines, such as TNF- $\alpha$ and IL-6, and increased expression of iNOS and nitric oxide (NO) [95]. Similarly, the JNK and P38 MAPK pathways also play important roles in inflammation. When the body has an inflammatory response, JNK can induce apoptosis and promote the activation of inflammatory factors TNF- $\alpha$ and IL-1 $\beta$ [96]. Inhibition of the p38/MAPK signalling pathway in airway smooth muscle plays an anti-inflammatory role by reducing the secretion of the inflammatory factor TNF- $\alpha$.

Interestingly, although LPS can induce inflammation through different signalling pathways, many studies have shown that SCFAs can inhibit LPS-induced inflammation through the above GPCRs and HDAC (Figure 1). For example, butyrate and propionate reduce the expression of TNF and nitric oxide synthase (NOS) in LPS-induced monocytes [97]. Furthermore, butyrate treatment can induce the phosphorylation of ERK, p38, JNK and NF-kB p65 through TLR4 in colon cancer cells [98]. Acetate restrains LPS-induced TNF $\alpha$ secretion from mice and human mononuclear cells by activating FFAR receptors [99]. In other studies, butyrate and propionate treatment can inhibit the secretion of $\mathrm{TNF} \alpha$ and the activity of NF-KB and up-regulate the expression of anti-inflammatory factors IL-10 in LPS-activated mononuclear cells and neutrophils by HDAC inhibition $[84,100,101]$. Additionally, SCFAs can down-regulate the expression of IL- 8 in airway inflammation by activating FFAR2 and FFAR3 receptors [102]. In macrophages, butyrate exerts anti-inflammatory effects by reducing the production of iNOS, TNF $\alpha$, MCP-1 and IL-6 through FFAR3 receptor [53], and cytokines such as IFN- $\gamma$ can increase GPR109A expression [103]. These anti-inflammatory effects are attributed to the activation 
of FFAR2, FFAR3 and GPR109A receptors; however, whether LPS induction affects the inflammatory responses has not been directly described.

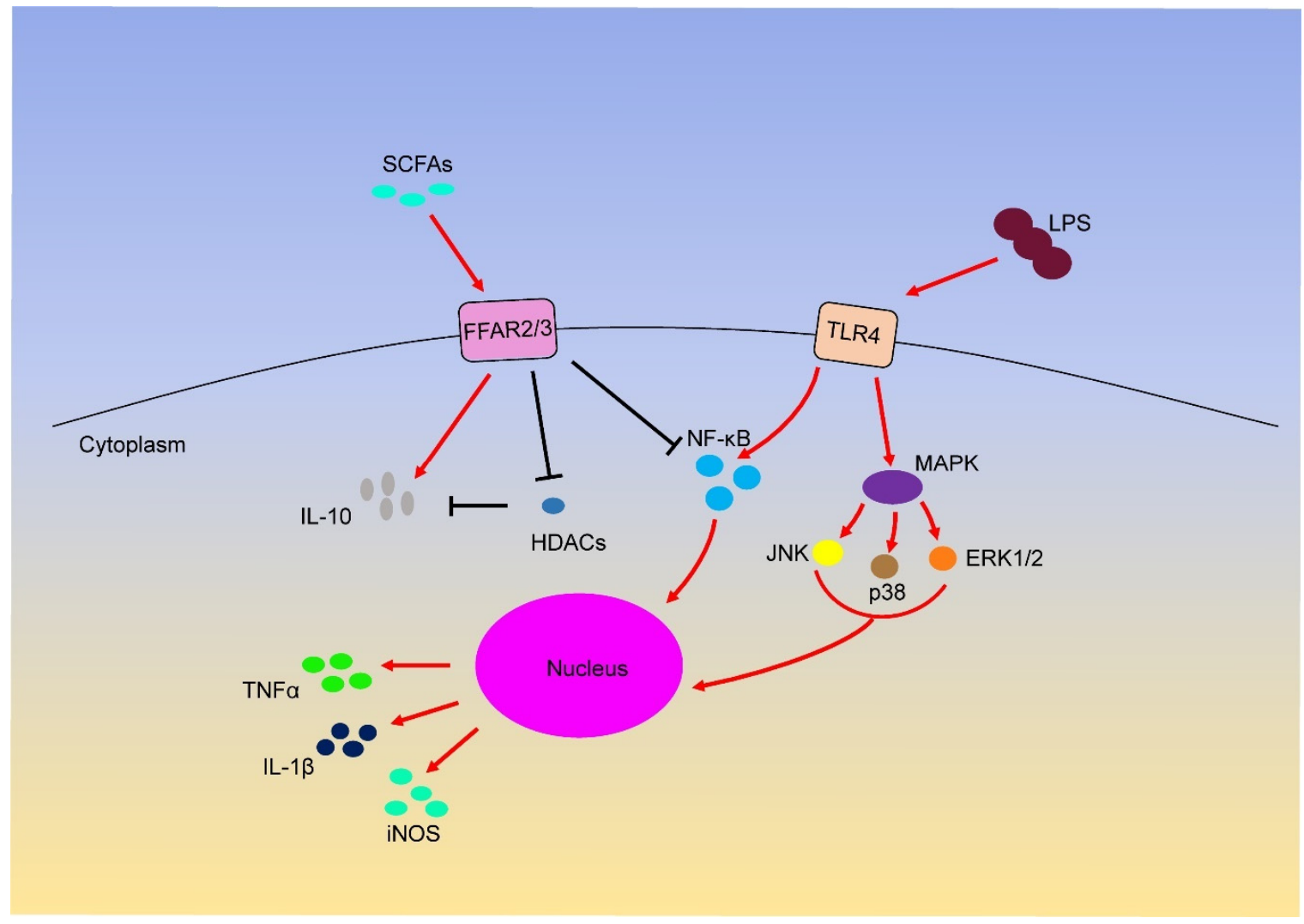

Figure 1. Short-chain fatty acids (SCFAs) regulates inflammation through FFAR2/3 receptor.

Although it has been widely reported that SCFAs play anti-inflammatory roles through different signalling pathways, some studies have found that SCFAs also play pro-inflammatory roles through GPCRs. For example, Kim et al. found that SCFAs activate GPR41 and GPR43 on intestinal epithelial cells to protect immunity and tissue inflammation in C57BL6 mice without FFAR2 or FFAR3 receptors [104]. The cause may be due to the authors using different SCFAs to activate the receptor. In this article, ethanol as SCFA may not be desirable. Strictly speaking, acetic acid or acetate is the appropriate experimental material to study SCFA.

\section{SCFAs and Glucose Metabolism}

Glucose is phosphorylated by hexokinase to form glucose 6-phosphate, which enters the glycolysis pathway and produces ATP for energy supply or glycogen for energy storage. The liver and skeletal muscles are important tissues for glucose metabolism. The regulation of blood glucose balance includes two aspects: the generation of blood glucose (feeding and gluconeogenesis) and consumption of blood glucose (exercise consumption and glycogen storage). The blood glucose concentration is regulated by complex hormones, among which the main ones are glucagon secreted by islet $\alpha$ cells and insulin secreted by islet $\beta$ cells. Studies have shown that the activation of FFAR3 by SCFA can stimulate the secretion of intestinal hormone PYY in endocrine cells, enhancing the absorption of glucose in muscle and adipose tissue and producing a sense of satiety and reduced food intake (Figure 2) [105-107]. Moreover, SCFA can stimulate the secretion of glucagon-like peptide-1 (GLP-1) by activating FFAR2, which indirectly regulates blood glucose levels by increasing insulin secretion and decreasing pancreatic glucagon secretion $[108,109]$. In addition to glucagon and insulin, leptin also plays an important role in blood glucose balance. Leptin is an aliphatic factor secreted by adipocytes 
and mainly regulates food intake, body weight and energy metabolism through the central nervous system. Sakakibara et al. found that SCFAs can increase leptin secretion by activating FFAR2 in vivo or in vitro [110]. Fujikawa et al. found that leptin promotes glucose uptake in brown adipose tissue and the soleus muscle and improves liver metabolism by acting on gamma-aminobutyric acid (GABA) and optic nerve melanocortin (POMC) neurons in the hypothalamus [111]. Additionally, leptin can directly promote the synthesis of liver glycogen and muscle blood glucose uptake [112,113].

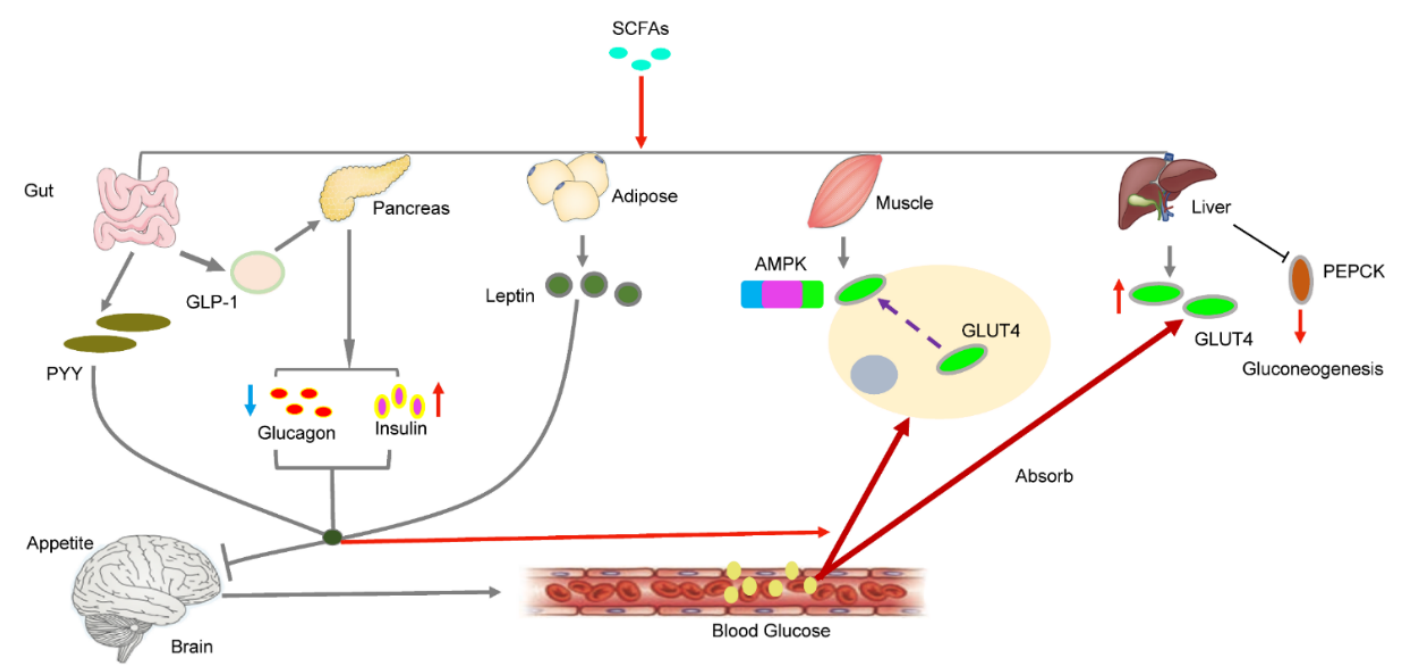

Figure 2. SCFAs regulates blood sugar by regulating the secretion of hormones in different tissues.

Furthermore, SCFAs have functions other than regulating blood sugar balance through hormones. Many glucose transporters are found on the cell. GLUT4, a speed-limiting protein that allows glucose to enter the cell, is mainly found in skeletal muscle cells. Studies have shown that short-chain fatty acids can increase the expression of GLUT4 and translocate it to the cell membrane, promoting the absorption of more glucose by myoblasts [114]. In the same study, the authors also found that SCFAs phosphorylated AMPK and its downstream product ACC. Hong et al. found that butyric acid increased the phosphorylation of AMPK in high-fat-fed mice [115]. SCFAs directly activate AMPK by increasing the ratio of AMP/ATP [116]. In skeletal muscle, AMPK activation inhibits glycogen and protein synthesis and promotes glucose transport and fatty acid oxidation $[117,118]$. In the liver, AMPK activation reduces the gene expression of glucose 6-phosphatase (G6Pase) and phosphoenolpyruvate carboxy-kinase (PEPCK), which are the key enzymes of gluconeogenesis [110]. Similar results were found by Kondo and Gao et al. In their study, SCFA directly activated the AMPK signalling pathway by increasing the AMP/ATP ratio in the muscles and liver $[13,119]$. AMPK can affect many downstream signalling pathways, such as mTOR, PGC-1A and $\mathrm{FOXO}_{3}$ [120-122]; however, whether these signalling pathways are related to glucose metabolism activated by SCFA remains to be further studied.

\section{SCFAs and Lipid Metabolism}

In three generations of substance metabolism, lipid metabolism is a key process that short-chain fatty acids can regulate. As members of the fatty acid family, SCFAs provide a substrate for lipid synthesis. Zambell et al. proved that acetate and butyrate are the main synthetic lipid substrates in rat colonic epithelial cells, which convert SCFAs into acetyl-CoA [123]. Similarly, Kindt et al. found that the intestinal microbiota promotes liver fatty acid metabolism by providing a high level of acetate as a precursor to the synthesis of palmitate and stearate [124]. Acetyl-CoA can not only enter the tricarboxylic acid cycle to generate energy but also generate palmitic acid under the action of the cytosolic enzyme system, which can transfer to mitochondria to extend the carbon chain and form triglycerides with other substances stored in adipose tissue. SCFAs are not only involved in lipid 
metabolism as a substrate but also can be used as a regulatory factor to regulate lipid metabolism. The experiment of $\mathrm{Li}$ et al. showed that butyric acid increased the oxidation of fatty acids in brown adipose tissue and improved the obesity and insulin resistance caused by diet [26]. Butyric acid can also promote the browning of white tissue, reduce the size of adipose cells morphologically, and increase the number of multicellular adipose cells [13].

In addition to glucose metabolism, AMPK signalling also plays a role in lipid metabolism (Figure 3). Previous studies have shown that AMPK activation increases PGC- $1 \alpha$ expression in adipose tissue and skeletal muscle [125-128]. Additionally, PGC-1 $\alpha$ regulates the transcription activity of various transcription factors, including peroxisome proliferator-activated receptor $\alpha$ (PPAR $\alpha)$ and peroxisome proliferator-activated receptor $\gamma$ (PPAR $\gamma)[13,129-131]$. Huang et al. found that activation of the AMPK signalling pathway in $\mathrm{db} / \mathrm{db}$ mice increased the expression of PPAR $\alpha$ and p-ACC in the liver, reducing the levels of triglycerides and free fatty acids [132]. Unfortunately, SCFAs were not used as an activator of AMPK in this study. However, in another study, the authors also found consistent results after activating AMPK using SCFAs [114]. Additionally, hormone-sensitive lipase (HSL) and adipose triglyceride lipase (ATGL), as the main enzymes of lipolysis, are regulated by AMPK. Studies have shown that the activated AMPK signalling pathway can promote the expression of HSL and ATGL and promote lipolysis [133-135]. However, other studies have reported different results. Houslay et al. found that SCFA inhibited adenylate cyclase, reducing cAMP production by ATP and protein kinase A (PKA) activity [46]. Subsequent studies have shown that reduced PKA activity leads to dephosphorylation and inactivation of HSL in adipose tissue [136]. Similarly, Jocken et al. found that acetate played an anti-lipolysis role by inhibiting HSL phosphorylation activity in human multipotent adipose tissue-derived stem cells [137]. Reducing the plasma levels of free fatty acids by inhibiting intracellular lipolysis may also regulate lipid metabolism by SCFA. Moreover, the activation of AMPK in rat liver cancer cells inhibited the synthesis of liver fatty acids by inhibiting sterol regulatory element-binding protein 1C (SREBP-1c, the main regulator of liver adipogenic gene expression) [138]. Furthermore, PGC- $1 \alpha$ regulates cholesterol, lipid and sugar metabolism. In summary, AMPK activation triggers the expression of PGC- $1 \alpha$, and SREBP-1c is a potential target.

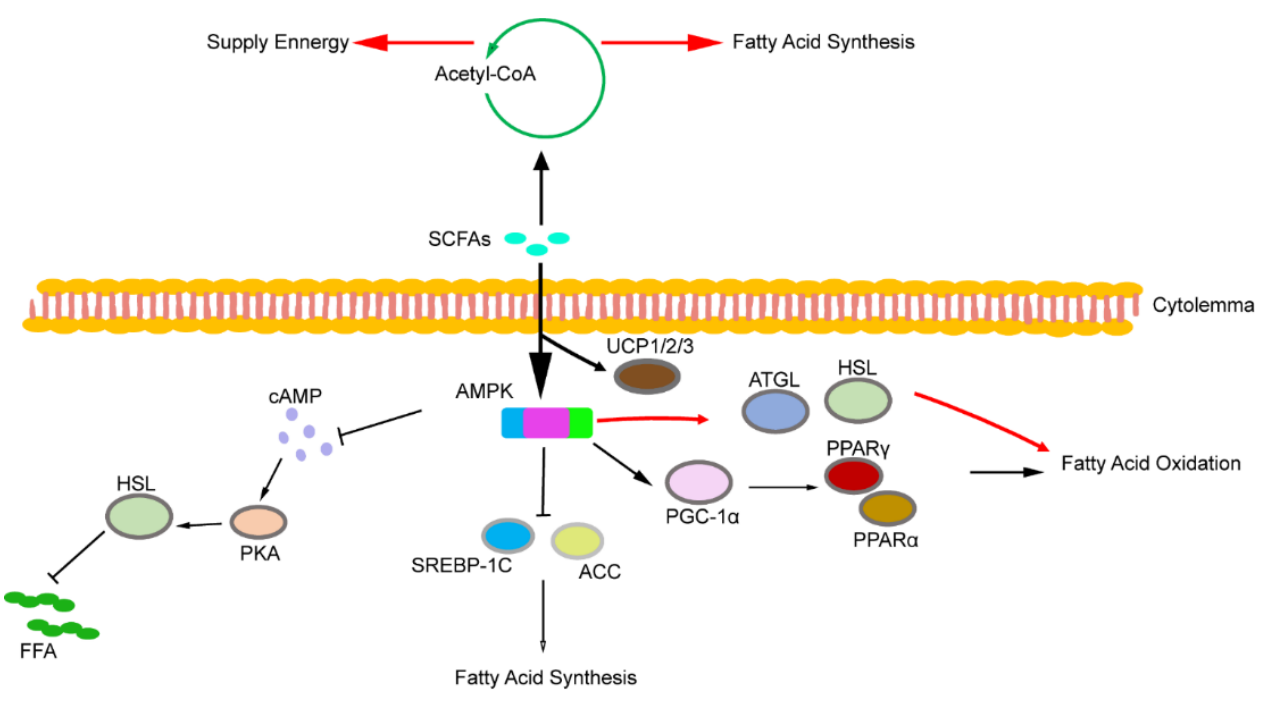

Figure 3. SCFAs regulates lipid metabolism by increasing fatty acid oxidation, reducing lipid deposition and heat production.

The uncoupling protein (UCP) plays an important role in lipid metabolism. There are three main subtypes in adipose tissue-UCP1, UCP2, and UCP3-which limit ATP synthesis, increase thermogenesis, and allow fatty acid oxidation to reduce lipid deposition. Gao et al. found that SCFA can increase the protein expression of PGC-1 and UCP-1 in brown adipose tissue [13]. Besten et al. found that SCFAs stimulate mitochondrial fatty acid oxidation by activating the UCP2-AMPK-ACC 
signalling pathway in human HepG2 hepatocytes and mouse 3T3L1 adipocytes [139]. Hong et al. found that butyrate upregulated the expression of UCP2, UCP3 and fatty acid oxidase in skeletal muscle. After butyrate administration, histone markers H3K9Ac with high expression of gene activation were detected in the promoter regions of adiponectin receptor 1/2, Ucp2 and Ucp3 in the muscle of obese mice [115]. Thus, butyrate not only increases heat production and lipid consumption through UCP but also improves lipid metabolism by activating adiponectin. Other genes, such as leptin, may also play a role in the regulation of lipid metabolism by SCFA, a topic that is not discussed too much here.

\section{Summary}

Overall, SCFAs have been shown to benefit many aspects of the body's metabolism. SCFAs have become a hot topic among researchers in terms of their initial food intake, intestinal flora composition and subsequent regulation of metabolism. Although many studies have investigated the role of SCFAs in inflammation, glucose metabolism and lipid metabolism, no systematic review exists to elucidate the SCFA-related signalling pathway in inflammation, glucose metabolism and lipid metabolism. Thus, we hope that this review increases awareness of the dominant roles of SCFAs in inflammation, glucose and lipid metabolism.

In studies of inflammation, although some studies have shown that SCFA is detrimental, most studies have shown that SCFA can reduce inflammation. However, in the existing studies, we found that butyrate was favoured by most researchers in the studies on SCFA-associated inflammation; few reports concerned other SCFAs. Thus, the inhibitory effect of different SCFAs in the same inflammatory model must be studied. The role of SCFAs in inflammation requires further study. Additionally, the regulation of glucose metabolism by SCFAs is mainly achieved by maintaining blood glucose stability. The effects of insulin and glucagon secretion are crucial for regulating glucose metabolism. Regarding lipid metabolism, SCFAs can increase fatty acid oxidation, inhibit fatty acid synthesis, increase heat production and reduce fat storage.

SCFAs have demonstrated a strong ability to regulate metabolism, but the regulatory network of SCFAs is very complex and the underlying molecular mechanism remains unclear. And the current study still has limitations. For example, although mice and other laboratory animals are used as model animals to study whether it is applicable to humans, but whether these animal data are fully applicable to humans is still a question worth exploring. However, studies in humans are mainly carried out using available mature cell lines or analysing SCFAs residue in faeces, and the inability to obtain data in vivo is still a big problem. Most of the current studies have focused on butyrate; whether it fully represents SCFAs is questionable. Although exogenous supplements can improve metabolism, could they be used in humans? Currently, there are no mature SCFA products on the market. Follow-up studies should focus on the development of effective SCFAs for clinical use.

Funding: This study was supported by the National Natural Science Foundation of China (No. 31972524, No. 31530073), the Sichuan Science and Technology Support Program (No. 2016NYZ0050; No. SCCXTD-2020-08), the earmarked fund for China Agriculture Research System (No. CARS-36-05B).

Conflicts of Interest: The authors declare no conflict of interest.

\section{References}

1. Cook, S.I.; Sellin, J.H. Review Article: Short Chain Fatty Acids in Health and Disease. Aliment. Pharmacol Ther. 1998, 12, 499-507. [CrossRef]

2. Cummings, J.H.; Pomare, E.W.; Branch, W.J.; Naylor, C.P.; Macfarlane, G.T. Short Chain Fatty Acids in Human Large Intestine, Portal, Hepatic and Venous Blood. Gut 1987, 28, 1221-1227. [CrossRef] [PubMed]

3. Louis, P.; Flint, H.J. Formation of Propionate and Butyrate by the Human Colonic Microbiota. Environ. Microbiol. 2017, 19, 29-41. [CrossRef] [PubMed]

4. Bergman, E.N. Energy Contributions of Volatile Fatty Acids from the Gastrointestinal Tract in Various Species. Physiol. Rev. 1990, 70, 567-590. [CrossRef] 
5. Macfarlane, S.; Macfarlane, G.T. Regulation of Short-Chain Fatty Acid Production. Proc. Nutr. Soc. 2003, 62, 67-72. [CrossRef] [PubMed]

6. Ruiz-Aceituno, L.; Esteban-Torres, M.; James, K.; Moreno, F.J.; Sinderen, D.V. Metabolism of Biosynthetic Oligosaccharides by Human-Derived Bifidobacterium Breve Ucc2003 and Bifidobacterium Longum Ncimb 8809. Int. J. Food Microbiol. 2020, 316, 108476. [CrossRef]

7. Horiuchi, H.; Kamikado, K.; Aoki, R.; Suganuma, N.; Nishijima, T.; Nakatani, A.; Kimura, I. Bifidobacterium Animalis Subsp. Lactis Gcl2505 Modulates Host Energy Metabolism Via the Short-Chain Fatty Acid Receptor Gpr43. Sci. Rep. 2020, 10, 4158. [CrossRef]

8. Smith, E.A.; Macfarlane, G.T. Enumeration of amino acid fermenting bacteria in the human large intestine: Effects of $\mathrm{pH}$ and starch on peptide metabolism and dissimilation of amino acids. FEMS Microbiol. Ecol. 1998, 25, 355-368. [CrossRef]

9. Dai, Z.L.; Wu, G.; Zhu, W.Y. Amino acid metabolism in intestinal bacteria: Links between gut ecology and host health. Front. Biosci. 2011, 16, 1768-1786. [CrossRef]

10. Duncan, S.H.; Louis, P.; Thomson, J.M.; Flint, H.J. The role of $\mathrm{pH}$ in determining the species composition of the human colonic microbiota. Environ. Microbiol. 2009, 11, 2112-2122. [CrossRef]

11. Youngblut, N.D.; Reischer, G.H.; Walters, W.A.; Schuster, N.; Walzer, C.; Stalder, G.; Ley, R.E.; Farnleitner, A.H. Host diet and evolutionary history explain different aspects of gut microbiome diversity among vertebrate clades. Nat. Commun. 2019, 10, 2200. [CrossRef] [PubMed]

12. Besten, G.D.; Eunen, K.V.; Groen, A.K.; Venema, K.; Reijngoud, D.J.; Bakker, B.M. The role of short-chain fatty acids in the interplay between diet, gut microbiota, and host energy metabolism. J. Lipid Res. 2013, 54, 2325-2340. [CrossRef] [PubMed]

13. Gao, Z.; Yin, J.; Zhang, J.; Ward, R.E.; Martin, R.J.; Lefevre, M.; Cefalu, W.T.; Ye, J. Butyrate Improves Insulin Sensitivity and Increases Energy Expenditure in Mice. Diabetes 2009, 58, 1509-1517. [CrossRef] [PubMed]

14. Fushimi, T.; Suruga, K.; Oshima, Y.; Fukiharu, M.; Tsukamoto, Y.; Goda, T. Dietary Acetic Acid Reduces Serum Cholesterol and Triacylglycerols in Rats Fed a Cholesterol-Rich Diet. Br. J. Nutr. 2006, 95, 916-924. [CrossRef]

15. Demigné, C.; Morand, C.; Levrat, M.A.; Besson, C.; Moundras, C.; Rémésy, C. Effect of Propionate on Fatty Acid and Cholesterol Synthesis and on Acetate Metabolism in Isolated Rat Hepatocytes. Br. J. Nutr. 1995, 74, 209-219. [CrossRef] [PubMed]

16. Todesco, T.; Rao, A.V.; Bosello, O.; Jenkins, D.J. Propionate Lowers Blood Glucose and Alters Lipid Metabolism in Healthy Subjects. Am. J. Clin. Nutr. 1991, 54, 860-865. [CrossRef]

17. Brown, L.; Rosner, B.; Willett, W.W.; Sacks, F.M. Cholesterol-Lowering Effects of Dietary Fiber: A Meta-Analysis. Am. J. Clin. Nutr. 1999, 69, 30-42. [CrossRef]

18. Causey, J.L.; Feirtag, J.M.; Gallaher, D.D.; Tungland, B.C.; Slavin, J.L. Effects of Dietary Inulin on Serum Lipids, Blood Glucose and the Gastrointestinal Environment in Hypercholesterolemic Men. Nutr. Res. 2000, 20, 191-201. [CrossRef]

19. Canfora, E.E.; Jocken, J.W.; Blaak, E.E. Short-Chain Fatty Acids in Control of Body Weight and Insulin Sensitivity. Nat. Rev. Endocrinol. 2015, 11, 577-591. [CrossRef]

20. Vadder, F.D.; Kovatcheva-Datchary, P.; Zitoun, C.; Duchampt, A.; Backhed, F.; Mithieux, G. Microbiota-Produced Succinate Improves Glucose Homeostasis Via Intestinal Gluconeogenesis. Cell Metab. 2016, 24, 151-157. [CrossRef]

21. Lewis, K.; Lutgendorff, F.; Phan, V.; Söderholm, J.D.; Sherman, P.M.; McKay, D.M. Enhanced Translocation of Bacteria across Metabolically Stressed Epithelia Is Reduced by Butyrate. Inflamm. Bowel Dis. 2010, 16, 1138-1148. [CrossRef] [PubMed]

22. Peng, L.; Li, Z.; Green, R.S.; Holzman, I.R.; Lin, J. Butyrate Enhances the Intestinal Barrier by Facilitating Tight Junction Assembly Via Activation of Amp-Activated Protein Kinase in Caco-2 Cell Monolayers. J. Nutr. 2009, 139, 1619-1625. [CrossRef] [PubMed]

23. Gaudier, E.; Rival, M.; Buisine, M.P.; Robineau, I.; Hoebler, C. Butyrate Enemas Upregulate Muc Genes Expression but Decrease Adherent Mucus Thickness in Mice Colon. Physiol. Res. 2009, 58, 111-119. [PubMed]

24. O'Keefe, S.J.D. Diet, Microorganisms and Their Metabolites, and Colon Cancer. Nat. Rev. Gastroenterol. Hepatol. 2016, 13, 691-706. [CrossRef]

25. Brown, E.M.; Sadarangani, M.; Finlay, B.B. The Role of the Immune System in Governing Host-Microbe Interactions in the Intestine. Nat. Immunol. 2013, 14, 660-667. [CrossRef] 
26. Li, Z.; Yi, C.; Katiraei, S.; Kooijman, S.; Zhou, E.; Chung, C.K.; Gao, Y.; Heuvel, J.V.D.; Meijer, O.C.; Berbée, J.F.P.; et al. Butyrate Reduces Appetite and Activates Brown Adipose Tissue Via the Gut-Brain Neural Circuit. Gut 2018, 67, 1269-1279. [CrossRef]

27. Mollica, M.P.; Raso, G.M.; Cavaliere, G. Butyrate Regulates Liver Mitochondrial Function, Efficiency, and Dynamics in Insulin-Resistant Obese Mice. Diabetes 2017, 66, 1405-1418. [CrossRef]

28. Vadder, F.D.; Kovatcheva-Datchary, P.; Goncalve, D.; Vinera, J.; Zitoun, C.; Duchampt, A.; Bäckhed, F.; Mithieux, G. Microbiota-Generated Metabolites Promote Metabolic Benefits Via Gut-Brain Neural Circuits. Cell 2014, 156, 84-96. [CrossRef]

29. Szentirmai, É.; Millican, N.S.; Massie, A.R.; Kapás, L. Butyrate, a Metabolite of Intestinal Bacteria, Enhances Sleep. Sci. Rep. 2019, 9, 7035. [CrossRef]

30. Brown, A.J.; Goldsworthy, S.M.; Barnes, A.A.; Eilert, M.M.; Tcheang, L.; Daniels, D.; Muir, A.I.; Wigglesworth, M.J.; Kinghorn, I.; Fraser, N.J.; et al. The Orphan G Protein-Coupled Receptors Gpr41 and Gpr43 Are Activated by Propionate and Other Short Chain Carboxylic Acids. J. Biol. Chem. 2003, 278, 11312-11319. [CrossRef]

31. Poul, E.L.; Loison, C.; Struyf, S.; Springael, J.; Lannoy, V.; Decobecq, M.; Brezillon, S.; Dupriez, V.; Vassart, G.; Damme, J.V.; et al. Functional Characterization of Human Receptors for Short Chain Fatty Acids and Their Role in Polymorphonuclear Cell Activation. J. Biol. Chem. 2003, 278, 25481-25489. [CrossRef] [PubMed]

32. Milligan, G.; Stoddart, L.A.; Smith, N.J. Agonism and Allosterism: The Pharmacology of the Free Fatty Acid Receptors Ffa2 and Ffa3. Br. J. Pharmacol. 2009, 158, 146-153. [CrossRef] [PubMed]

33. Brown, A.J.; Jupe, S.; Briscoe, C.P. A Family of Fatty Acid Binding Receptors. DNA Cell Biol. 2005, $24,54-61$. [CrossRef] [PubMed]

34. Kebede, M.A.; Alquier, T.; Latour, M.G.; Poitout, V. Lipid Receptors and Islet Function: Therapeutic Implications? Diabetes Obes. Metab. 2009, 4, 10-20. [CrossRef] [PubMed]

35. Halpern, K.B.; Veprik, A.; Rubins, N.; Naaman, O.; Walker, M.D. Gpr41 Gene Expression Is Mediated by Internal Ribosome Entry Site (Ires)-Dependent Translation of Bicistronic Mrna Encoding Gpr40 and Gpr41 Proteins. J. Biol. Chem. 2012, 287, 20154-20163. [CrossRef]

36. Tazoe, H.; Otomo, Y.; Karaki, S.; Kato, I.; Fukami, Y.; Terasaki, M.; Kuwahara, A. Expression of Short-Chain Fatty Acid Receptor Gpr41 in the Human Colon. Biomed. Res. 2009, 30, 149-156. [CrossRef]

37. Sykaras, A.G.; Demenis, C.; Case, R.M.; McLaughlin, J.T.; Smith, C.P. Duodenal Enteroendocrine I-Cells Contain Mrna Transcripts Encoding Key Endocannabinoid and Fatty Acid Receptors. PLoS ONE 2012, 7, e42373. [CrossRef]

38. Karaki, S.; Mitsui, R.; Hayashi, H.; Kato, I.; Sugiya, H.; Iwanaga, T.; Furness, J.B.; Kuwahara, A. Short-Chain Fatty Acid Receptor, Gpr43, Is Expressed by Enteroendocrine Cells and Mucosal Mast Cells in Rat Intestine. Cell Tissue Res. 2006, 324, 353-360. [CrossRef]

39. Hong, Y.; Nishimura, Y.; Hishikawa, D.; Tsuzuki, H.; Miyahara, H.; Gotoh, C.; Choi, K.; Feng, D.D.; Chen, C.; Lee, H.; et al. Acetate and Propionate Short Chain Fatty Acids Stimulate Adipogenesis Via Gpcr43. Endocrinology 2005, 146, 5092-5099. [CrossRef]

40. Maslowski, K.; Vieira, A.T.; Ng, A.; Kranich, J.; Sierro, F.; Yu, D.; Schilter, H.C.; Rolph, M.S.; Mackay, F.; Artis, D.; et al. Regulation of Inflammatory Responses by Gut Microbiota and Chemoattractant Receptor Gpr43. Nature 2009, 461, 1282-1286. [CrossRef]

41. Nilsson, C.; Swolin-Eide, D.; Ohlsso, C.; Eriksson, E.; Ho, H.; Björntorp, P.; Holmäng, A. Reductions in Adipose Tissue and Skeletal Growth in Rat Adult Offspring after Prenatal Leptin Exposure. J. Endocrinol. 2003, 176, 13-21. [CrossRef] [PubMed]

42. Smith, P.M.; Howitt, M.R.; Panikov, N.; Michaud, M.; Gallini, C.A.; Bohlooly-Y, M.; Glickman, J.N.; Garrett, W.S. The Microbial Metabolites, Short Chain Fatty Acids, Regulate Colonic Treg Cell Homeostasis. Science 2013, 341, 569-573. [CrossRef] [PubMed]

43. Pingitore, A.; Gonzalez-Abuin, N.; Ruz-Maldonado, I.; Huang, G.C.; Frost, G.; Persaud, S.J. Short Chain Fatty Acids Stimulate Insulin Secretion and Reduce Apoptosis in Mouse and Human Islets in Vitro: Role of Free Fatty Acid Receptor 2. Diabetes Obes. Metab. 2019, 21, 330-339. [CrossRef] [PubMed]

44. Brown, A.J.; Tsoulou, C.; Ward, E.; Gower, E.; Bhudia, N.; Chowdhury, F.; Dean, T.W.; Faucher, N.; Gangar, A.; Dowell, S.J. Pharmacological Properties of Acid N-Thiazolylamide Ffa2 Agonists. Pharmacol. Res. Perspect. 2015, 3, e00141. [CrossRef] [PubMed] 
45. Forbes, S.; Stafford, S.; Coope, G.; Heffron, H.; Real, K.; Newman, R.; Davenport, R.; Barnes, M.; Grosse, J.; Cox, H. Selective Ffa2 Agonism Appears to Act Via Intestinal Pyy to Reduce Transit and Food Intake but Does Not Improve Glucose Tolerance in Mouse Models. Diabetes 2015, 64, 3763-3771. [CrossRef] [PubMed]

46. Houslay, M.D.; Milligan, G. Tailoring Camp-Signalling Responses through Isoform Multiplicity. Trends Biochem. Sci. 1997, 22, 217-224. [CrossRef]

47. Kimura, I.; Inoue, D.; Hirano, K.; Tsujimoto, G. The SCFA Receptor Gpr43 and Energy Metabolism. Front. Endocrinol. 2014, 5, 85. [CrossRef] [PubMed]

48. Pirozzi, C.; Francisco, V.; Guida, F.D.; Gómez, R.; Lago, F.; Pino, J.; Meli, R.; Gualillo, O. Butyrate Modulates Inflammation in Chondrocytes Via Gpr43 Receptor. Cell Physiol. Biochem. 2018, 51, 228-243. [CrossRef]

49. Nakajima, A.; Nakatani, A.; Hasegawa, S.; Irie, J.; Ozawa, K.; Tsujimoto, G.; Suganami, T.; Itoh, H.; Kimura, I. The Short Chain Fatty Acid Receptor Gpr43 Regulates Inflammatory Signals in Adipose Tissue M2-Type Macrophages. PLoS ONE 2017, 12, e0179696. [CrossRef]

50. Mizuta, K.; Matoba, A.; Shibata, S.; Masaki, E.; Sr, C.W.E. Obesity-Induced Asthma: Role of Free Fatty Acid Receptors. Jpn. Dent. Sci. Rev. 2019, 55, 103-107. [CrossRef]

51. Samuel, B.S.; Shaito, A.; Motoike, T.; Rey, F.E.; Backhed, F.; Manchester, J.K.; Hammer, R.E.; Williams, S.C.; Crowley, J.; Yanagisawa, M.; et al. Effects of the Gut Microbiota on Host Adiposity Are Modulated by the Short-Chain Fatty-Acid Binding G Protein-Coupled Receptor, Gpr41. Proc. Natl. Acad. Sci. USA 2008, 105, 16767-16772. [CrossRef] [PubMed]

52. Kimura, I.; Inoue, D.; Maeda, T.; Hara, T.; Ichimura, A.; Miyauchi, S.; Kobayashi, M.; Hirasawa, A.; Tsujimoto, G. Short-Chain Fatty Acids and Ketones Directly Regulate Sympathetic Nervous System Via G Protein-Coupled Receptor 41 (Gpr41). Proc. Natl. Acad. Sci. USA 2011, 108, 8030-8035. [CrossRef] [PubMed]

53. Ohira, H.; Fujioka, Y.; Katagiri, C.; Mamoto, R.; Aoyama-Ishikawa, M.; Amako, K.; Izumi, Y.; Nishiumi, S.; Yoshida, M.; Usami, M.; et al. Butyrate Attenuates Inflammation and Lipolysis Generated by the Interaction of Adipocytes and Macrophages. J. Atheroscler. Thromb. 2013, 20, 425-442. [CrossRef] [PubMed]

54. Li, M.; Esch, B.C.A.M.; Wagenaar, G.T.M.; Garssen, J.; Folkerts, G.; Henricks, P.A.J. Pro- and Anti-Inflammatory Effects of Short Chain Fatty Acids on Immune and Endothelial Cells. Eur. J. Pharmacol. 2018, 831, 52-59. [CrossRef]

55. Miyamoto, J.; Kasubuchi, M.; Nakajima, A.; Kimura, I. Anti-Inflammatory and Insulin-Sensitizing Effects of Free Fatty Acid Receptors. Handb. Exp. Pharmacol. 2016, 236, 221-231.

56. Nilsson, N.E.; Kotarsky, K.; Owman, C.; Olde, B. Identification of a Free Fatty Acid Receptor, Ffa2r, Expressed on Leukocytes and Activated by Short-Chain Fatty Acids. Biochem. Biophys. Res. Commun. 2003, 303, 1047-1052. [CrossRef]

57. Stoddart, L.A.; Smith, N.J.; Jenkins, L.; Brown, A.J.; Milligan, G. Conserved Polar Residues in Transmembrane Domains V, Vi, and Vii of Free Fatty Acid Receptor 2 and Free Fatty Acid Receptor 3 Are Required for the Binding and Function of Short Chain Fatty Acids. J. Biol. Chem. 2008, 283, 32913-32924. [CrossRef]

58. Colina, C.; Puhl, H.L.; Ikeda, S.R. Selective Tracking of Ffar3-Expressing Neurons Supports Receptor Coupling to N-Type Calcium Channels in Mouse Sympathetic Neurons. Sci. Rep. 2018, 8, 17379. [CrossRef]

59. Trompette, A.; Gollwitzer, E.S.; Yadava, K.; Sichelstiel, A.K.; Sprenger, N.; Ngom-Bru, C.; Blanchard, C.; Junt, T.; Nicod, L.P.; Harris, N.L.; et al. Gut Microbiota Metabolism of Dietary Fiber Influences Allergic Airway Disease and Hematopoiesis. Nat. Med. 2014, 20, 159-166. [CrossRef]

60. Pluznick, J.L.; Protzko, R.J.; Gevorgyan, H.; Peterlin, Z.; Sipos, A.; Han, J.; Brunet, I.; Wan, L.; Rey, F.; Wang, T.; et al. Olfactory Receptor Responding to Gut Microbiota-Derived Signals Plays a Role in Renin Secretion and Blood Pressure Regulation. Proc. Natl. Acad. Sci. USA 2013, 110, 4410-4415. [CrossRef]

61. Pluznick, J. A Novel SCFA Receptor, the Microbiota, and Blood Pressure Regulation. Gut Microb. 2014, 5, 202-207. [CrossRef] [PubMed]

62. Mizuta, K.; Sasaki, H.; Zhang, Y.; Matoba, A.; Sr, C.W.E. The Short-Chain Free Fatty Acid Receptor Ffar3 Is Expressed and Potentiates Contraction in Human Airway Smooth Muscle. Am. J. Physiol. Lung Cell Mol. Physiol. 2020, 318, L1248-L1260. [CrossRef] [PubMed]

63. Ørgaard, A.; Jepsen, S.L.; Holst, J.J. Short-Chain Fatty Acids and Regulation of Pancreatic Endocrine Secretion in Mice. Islets 2019, 11, 103-111. [CrossRef]

64. Priyadarshini, M.; Layden, B.T. Ffar3 Modulates Insulin Secretion and Global Gene Expression in Mouse Islets. Islets 2015, 7, e1045182. [CrossRef] 
65. Shimizu, H.; Masujima, Y.; Ushiroda, C.; Mizushima, R.; Taira, S.; Ohue-Kitano, R.; Kimura, I. Dietary Short-Chain Fatty Acid Intake Improves the Hepatic Metabolic Condition Via Ffar3. Sci. Rep. 2019, 9, 16574. [CrossRef] [PubMed]

66. Wanders, D.; Graff, E.C.; Judd, R.L. Effects of High Fat Diet on Gpr109A and Gpr81 Gene Expression. Biochem. Biophys. Res. Commun. 2012, 425, 278-283. [CrossRef]

67. Thangaraju, M.; Cresci, G.A.; Liu, K.; Ananth, S.; Gnanaprakasam, J.P.; Browning, D.D.; Mellinger, J.D.; Smith, S.B.; Digby, G.J.; Lambert, N.A.; et al. Gpr109A Is a G-Protein-Coupled Receptor for the Bacterial Fermentation Product Butyrate and Functions as a Tumor Suppressor in Colon. Cancer Res. 2009, 69, 2826-2832. [CrossRef]

68. Benyó, Z.; Gille, A.; Kero, J.; Csiky, M.; Suchánková, M.C.; Nüsing, R.M.; Moers, A.; Pfeffer, K.; Offermanns, S. Gpr109A (Puma-G/Hm74a) Mediates Nicotinic Acid-Induced Flushing. J. Clin. Investig. 2005, 115, 3634-3640. [CrossRef]

69. Zellner, C.; Pullinger, C.R.; Aouizerat, B.E.; Frost, P.H.; Kwok, P.; Malloy, M.J.; Kane, J.P. Variations in Human Hm74 (Gpr109b) and Hm74a (Gpr109A) Niacin Receptors. Human Mutat. 2005, 25, 18-21. [CrossRef]

70. Offermanns, S. Hydroxy-Carboxylic Acid Receptor Actions in Metabolism. Trends Endocrinol. Metab. 2017, 28, 227-236. [CrossRef]

71. Rezq, S.; Abdel-Rahman, A.A. Central Gpr109A Activation Mediates Glutamate-Dependent Pressor Response in Conscious Rats. J. Pharmacol. Exp. Ther. 2016, 356, 456-465. [CrossRef] [PubMed]

72. Li, Z.; Li, X.; Lin, S.; Chen, Y.; Ma, S.; Fu, Y.; Wei, C.; Xu, W. Nicotinic Acid Receptor Gpr109A Exerts Anti-Inflammatory Effects through Inhibiting the Akt/mTOR Signaling Pathway in Min6 Pancreatic B Cells. Ann. Clin. Lab. Sci. 2017, 47, 729-737. [PubMed]

73. Elangovan, S.; Pathania, R.; Ramachandran, S.; Ananth, S.; Padia, R.N.; Lan, L.; Singh, N.; Martin, P.M.; Hawthorn, L.; Prasad, P.D.; et al. The Niacin/Butyrate Receptor Gpr109A Suppresses Mammary Tumorigenesis by Inhibiting Cell Survival. Cancer Res. 2014, 74, 1166-1178. [CrossRef] [PubMed]

74. Priyadarshini, M.; Kotlo, K.U.; Dudeja, P.K.; Layden, B.T. Role of Short Chain Fatty Acid Receptors in Intestinal Physiology and Pathophysiology. Compr. Physiol. 2018, 8, 1091-1115. [PubMed]

75. Kaye, D.M.; Shihata, W.A.; Jama, H.A.; Tsyganov, K.; Ziemann, M.; Kiriazis, H.; Horlock, D.; Vijay, A.; Giam, B.; Vinh, A.; et al. Deficiency of Prebiotic Fiber and Insufficient Signaling through Gut Metabolite-Sensing Receptors Leads to Cardiovascular Disease. Circulation 2020, 141, 1393-1403. [CrossRef]

76. Wang, N.; Guo, D.; Tian, X.; Lin, H.; Li, Y.; Chen, S.; Fu, Y.; Xu, W.; Wei, C. Niacin Receptor Gpr109A Inhibits Insulin Secretion and Is Down-Regulated in Type 2 Diabetic Islet Beta-Cells. Gen. Comp. Endocrinol. 2016, 237, 98-108. [CrossRef]

77. Shi, Y.; Lai, X.; Ye, L.; Chen, K.; Cao, Z.; Gong, W.; Jin, L.; Wang, C.; Liu, M.; Liao, Y.; et al. Activated Niacin Receptor Hca2 Inhibits Chemoattractant-Mediated Macrophage Migration Via G $\beta \gamma /$ PKC/ERK1/2 Pathway and Heterologous Receptor Desensitization. Sci. Rep. 2017, 7, 42279. [CrossRef]

78. Borthakur, A.; Priyamvada, S.; Kumar, A.; Natarajan, A.A.; Gill, R.K.; Alrefai, W.A.; Dudeja, P.K. A Novel Nutrient Sensing Mechanism Underlies Substrate-Induced Regulation of Monocarboxylate Transporter-1. Am. J. Physiol. Gastrointest. Liver Physiol. 2012, 303, G1126-G1133. [CrossRef]

79. Linda Sealy, R.C. The Effect of Sodium Butyrate on Histone Modification. Cell 1978, 14, 115-121. [CrossRef]

80. Boffa, L.C.; Vidali, G.; Mann, R.S.; Allfrey, V.G. Suppression of Histone Deacetylation in Vivo and in Vitro by Sodium Butyrate. J. Biol. Chem. 1978, 253, 3364-3366.

81. Waldecker, M.; Kautenburger, T.; Daumann, H.; Busch, C.; Schrenk, D. Inhibition of Histone-Deacetylase Activity by Short-Chain Fatty Acids and Some Polyphenol Metabolites Formed in the Colon. J. Nutr. Biochem. 2008, 19, 587-593. [CrossRef] [PubMed]

82. Soliman, M.L.; Rosenberger, T.A. Acetate Supplementation Increases Brain Histone Acetylation and Inhibits Histone Deacetylase Activity and Expression. Mol. Cell Biochem. 2011, 352, 173-180. [CrossRef] [PubMed]

83. Bulusu, V.; Tumanov, S.; Michalopoulou, E.; Broek, N.J.; MacKay, G.; Nixon, C.; Dhayade, S.; Schug, Z.T.; Voorde, J.V.; Blyth, K.; et al. Acetate Recapturing by Nuclear Acetyl-CoA Synthetase 2 Prevents Loss of Histone Acetylation during Oxygen and Serum Limitation. Cell Rep. 2017, 18, 647-658. [CrossRef] [PubMed]

84. Chang, P.V.; Hao, L.; Offermanns, S.; Medzhitov, R. The Microbial Metabolite Butyrate Regulates Intestinal Macrophage Function Via Histone Deacetylase Inhibition. Proc. Natl. Acad. Sci. USA 2014, 111, 2247-2252. [CrossRef] [PubMed] 
85. Sun, M.; Wu, W.; Liu, Z.; Cong, Y. Microbiota Metabolite Short Chain Fatty Acids, Gpcr, and Inflammatory Bowel Diseases. J. Gastroenterol. 2017, 52, 1-8. [CrossRef]

86. Wu, J.; Zhou, Z.; Hu, Y.; Dong, S. Butyrate-Induced Gpr41 Activation Inhibits Histone Acetylation and Cell Growth. J. Genet. Genom. 2012, 39, 375-384. [CrossRef]

87. Czepiel, J.; Biesiada, G.; Brzozowski, T.; Ptak-Belowska, A.; Perucki, W.; Birczynska, M.; Jurczyszyn, A.; Strzalka, M.; Targosz, A.; Garlicki, A. The Role of Local and Systemic Cytokines in Patients Infected with Clostridium Difficile. J. Physiol. Pharmacol. 2014, 65, 695-703.

88. Park, B.S.; Lee, J. Recognition of Lipopolysaccharide Pattern by TLR4 Complexes. Exp. Mol. Med. 2013, 45, e66. [CrossRef]

89. Hagar, J.A.; Powell, D.A.; Aachoui, Y.; Ernst, R.K.; Miao, E.A. Cytoplasmic LPS Activates Caspase-11: Implications in TLR4-Independent Endotoxic shock. Science 2013, 341, 1250-1253. [CrossRef]

90. Adrie, C.; Pinsky, M.R. The Inflammatory Balance in Human Sepsis. Intensive Care Med. 2000, 26, 364-375. [CrossRef]

91. Baeuerle, P.A.; Baichwal, V.R. NF-Kappa B as a Frequent Target for Immunosuppressive and Anti-Inflammatory Molecules. Adv. Immunol. 1997, 65, 111-137.

92. Pahl, H.L. Activators and Target Genes of Rel/NF-Kappab Transcription Factors. Oncogene 1999, 18, $6853-6866$. [CrossRef] [PubMed]

93. Liu, S.F.; Malik, A.B. NF-Kappa B Activation as a Pathological Mechanism of Septic Shock and Inflammation. Am. J. Physiol. Lung Cell. Mol. Physiol. 2006, 290, L622-L645. [CrossRef] [PubMed]

94. Liu, S.; Feng, G.; Wang, G.; Liu, G. p38MAPK Inhibition Attenuates LPS-induced Acute Lung Injury Involvement of NF-kappaB Pathway. Eur. J. Pharmacol. 2008, 584, 159-165. [CrossRef] [PubMed]

95. Jeong, Y.; Du, R.; Zhu, X.; Yin, S.; Wang, J.; Cui, H.; Cao, W.; Lowenstein, C.J. Histone Deacetylase Isoforms Regulate Innate Immune Responses by Deacetylating Mitogen-Activated Protein Kinase Phosphatase-1. J. Leukoc. Biol. 2014, 95, 651-659. [CrossRef] [PubMed]

96. Subedi, L.; Venkatesan, R.; Kim, S.Y. Neuroprotective and Anti-Inflammatory Activities of Allyl Isothiocyanate Through Attenuation of JNK/NF-kB/TNF- $\alpha$ Signaling. Int. J. Mol. Sci. 2017, 18, 1423. [CrossRef]

97. Vinolo, M.A.R.; Rodrigues, H.G.; Hatanaka, E.; Sato, F.T.; Sampaio, S.C.; Curi, R. Suppressive Effect of Short-Chain Fatty Acids on Production of Proinflammatory Mediators by Neutrophils. J. Nutr. Biochem. 2011, 22, 849-855. [CrossRef]

98. Xiao, T.; Wu, S.; Yan, C.; Zhao, C.; Jin, H.; Yan, N.; Xu, J.; Wu, Y.; Li, C.; Shao, Q.; et al. Butyrate Upregulates the TLR4 Expression and the Phosphorylation of MAPKs and NK-кB in Colon Cancer Cell in vitro. Oncol. Lett. 2018, 16, 4439-4447. [CrossRef]

99. Masui, R.; Sasaki, M.; Funaki, Y.; Ogasawara, N.; Mizuno, M.; Iida, A.; Izawa, S.; Kondo, Y.; Ito, Y.; Tamura, Y.; et al. G Protein-Coupled Receptor 43 Moderates Gut Inflammation through Cytokine Regulation from Mononuclear Cells. Inflamm. Bowel Dis. 2013, 19, 2848-2856. [CrossRef]

100. Aoyama, M.; Kotani, J.; Usami, M. Butyrate and Propionate Induced Activated or Non-Activated Neutrophil Apoptosis via HDAC Inhibitor Activity but Without Activating GPR-41/GPR-43 Pathways. Nutrition 2010, 26, 653-661. [CrossRef]

101. Vinolo, M.A.R.; Rodrigues, H.G.; Nachbar, R.T.; Curi, R. Regulation of Inflammation by Short Chain Fatty Acids. Nutrients 2011, 3, 858-876. [CrossRef] [PubMed]

102. Halnes, I.; Baines, K.J.; Berthon, B.S.; MacDonald-Wicks, L.K.; Gibson, P.G.; Wood, L.G. Soluble Fibre Meal Challenge Reduces Airway Inflammation and Expression of GPR43 and GPR41 in Asthma. Nutrients 2017, 9, 57. [CrossRef] [PubMed]

103. Schaub, A.; Fütterer, A.; Pfeffer, K. PUMA-G, an IFN-gamma-inducible Gene in Macrophages Is a Novel Member of the Seven Transmembrane Spanning Receptor Superfamily. Eur. J. Immunol. 2001, 31, 3714-3739. [CrossRef]

104. Kim, M.H.; Kang, S.G.; Park, J.H.; Yanagisawa, M.; Kim, C.H. Short-chain Fatty Acids Activate GPR41 and GPR43 on Intestinal Epithelial Cells to Promote Inflammatory Responses in Mice. Gastroenterology 2013, 145, 396-406. [CrossRef] [PubMed]

105. Ribola, F.A.; Cançado, F.B.; Schoueri, J.H.M.; Toni, V.F.; Medeiros, V.H.; Feder, D. Effects of SGLT2 Inhibitors on Weight Loss in Patients With Type 2 Diabetes Mellitus. Eur. Rev. Med. Pharmacol. Sci. 2017, 21, 199-211. 
106. Batterham, R.L.; Cowley, M.A.; Small, C.J.; Herzog, H.; Cohen, M.A.; Dakin, C.L.; Wren, A.M.; Brynes, A.E.; Low, M.J.; Ghatei, M.A.; et al. Gut Hormone PYY(3-36) Physiologically Inhibits Food Intake. Nature 2002, 418, 650-654. [CrossRef]

107. Hoek, A.M.; Heijboer, A.C.; Corssmit, E.P.M.; Voshol, P.J.; Romijn, J.A.; Havekes, L.M.; Pijl, H. PYY3-36 Reinforces Insulin Action on Glucose Disposal in Mice Fed a High-Fat Diet. Diabetes 2004, 53, 1949-1952. [CrossRef]

108. Mazibuko, S.E.; Muller, C.J.F.; Joubert, E.; Beer, D.; Johnson, R.; Opoku, A.R.; Louw, J. Amelioration of Palmitate-Induced Insulin Resistance in $\mathrm{C}_{2} \mathrm{C}_{12}$ Muscle Cells by Rooibos (Aspalathus Linearis). Phytomedicine 2013, 20, 813-822. [CrossRef]

109. Barrera, J.G.; Sandoval, D.A.; D'Alessio, D.A.; Seeley, R.J. GLP-1 and Energy Balance: An Integrated Model of Short-Term and Long-Term Control. Nat. Rev. Endocrinol. 2011, 7, 507-516. [CrossRef]

110. Sakakibara, S.; Yamauchi, T.; Oshima, Y.; Tsukamoto, Y.; Kadowaki, T. Acetic acid activates hepatic AMPK and reduces hyperglycemia in diabetic KK-A(y) mice. Biochem. Biophys. Res. Commun. 2006, 344, 597-604. [CrossRef]

111. Fujikawa, T.; Berglund, E.D.; Patel, V.R.; Ramadori, G.; Vianna, C.R.; Vong, L.; Thorel, F.; Chera, S.; Herrera, P.L.; Lowell, B.B.; et al. Leptin Engages a Hypothalamic Neurocircuitry to Permit Survival in the Absence of Insulin. Cell Metab. 2013, 18, 431-444. [CrossRef] [PubMed]

112. Fujikawa, T.; Chuang, J.; Sakata, I.; Ramadori, G.; Coppari, R. Leptin Therapy Improves Insulin-Deficient Type 1 Diabetes by Cns-Dependent Mechanisms in Mice. Proc. Natl. Acad. Sci. USA 2010, 107, 17391-17396. [CrossRef] [PubMed]

113. Minokoshi, Y.; Kim, Y.; Peroni, O.D.; Fryer, L.G.; Müller, C.; Carling, D.; Kahn, B.B. Leptin Stimulates Fatty-Acid Oxidation by Activating Amp-Activated Protein Kinase. Nature 2002, 415, 339-343. [CrossRef] [PubMed]

114. Deng, B. Study the Mechanism of Calcium Signal- and Short Chain Fatty Acids-Regulated Glucose Metabolism. Ph.D. Thesis, Tianjin Medical University, Tianjin, China, 2018.

115. Hong, J.; Yimin Jia, Y.; Pan, S.; Jia, L.; Li, H.; Han, Z.; Cai, D.; Zhao, R. Butyrate Alleviates High Fat Diet-Induced Obesity through Activation of Adiponectin-Mediated Pathway and Stimulation of Mitochondrial Function in the Skeletal Muscle of Mice. Oncotarget 2016, 7, 56071-56082. [CrossRef]

116. Besten, G.; Gerding, A.; Dijk, T.H.; Ciapaite, J.; Bleeker, A.; Eunen, K.; Havinga, R.; Groen, A.K.; Reijngoud, D.J.; Bakker, B.M. Protection against the Metabolic Syndrome by Guar Gum-Derived Short-Chain Fatty Acids Depends on Peroxisome Proliferator-Activated Receptor $\Gamma$ and Glucagon-Like Peptide-1. PLoS ONE 2015, 10, e0136364. [CrossRef]

117. Merrill, G.F.; Kurth, E.J.; Hardie, D.G.; Winder, W.W. Aica Riboside Increases Amp Activated Protein Kinase, Fatty Acid Oxidati on, and Glucose Uptake in Rat Muscle. Am. J. Physiol. 1997, 273, E1107-E1119.

118. Hardie, D.G.; Hawley, S.A.; Scott, J.W. AMP-activated Protein Kinase-Development of the Energy Sensor Concept. J. Physiol. 2006, 574, 7-15. [CrossRef]

119. Kondo, T.; Kishi, M.; Fushimi, T.; Kaga, T. Acetic Acid Upregulates the Expression of Genes for Fatty Acid Oxidation Enzymes in Liver to Suppress Body Fat Accumulation. J. Agric. Food Chem. 2009, 57, 5982-5986. [CrossRef]

120. Kim, G.T.; Lee, S.H.; Kim, Y.M. Quercetin Regulates Sestrin 2-Ampk-Mtor Signaling Pathway and Induces Apoptosis Via Increased Intracellular Ros in Hct116 Colon Cancer Cells. J. Cancer Prev. 2013, 18, $264-270$. [CrossRef]

121. Liu, H.; Peng, H.; Xiang, H.; Guo, L.; Chen, R.; Zhao, S.; Chen, W.; Chen, P.; Lu, H.; Chen, S. TWEAK/Fn14 Promotes Oxidative Stress Through AMPK/PGC-1 $\alpha /$ MnSOD Signaling Pathway in Endothelial Cells. Mol. Med. Rep. 2017, 17, 1998-2004. [CrossRef]

122. Ma, W.; Wang, J.; Bu, X.; Zhang, H.; Zhang, J.; Zhang, X.; He, Y.; Wang, D.; Zhang, Z.; Meng, F. Effects of Polygonum Cuspidatum on AMPK-FOXO3 $\alpha$ Signaling Pathway in Rat Model of Uric Acid-Induced Renal Damage. Chin. J. Integr. Med. 2019, 25, 182-189. [CrossRef] [PubMed]

123. Zambell, K.L.; Fitch, M.D.; Fleming, S.E. Acetate and Butyrate Are the Major Substrates for De Novo Lipogenesis in Rat Colonic Epithelial Cells. J. Nutr. 2003, 133, 3509-3515. [CrossRef] [PubMed]

124. Kindt, A.; Liebisch, G.; Clacel, T.; Haller, D.; Hörmannsperger, G.; Yoon, H.; Kolmeder, D.; Sigruener, A.; Krautbauer, S.; Seeliger, C.; et al. The gut microbiota promotes hepatic fatty acid desaturation and elongation in mice. Nat. Commun. 2018, 9, 3760. [CrossRef] [PubMed] 
125. Taylor, E.B.; Lamb, J.D.; Hurst, R.W.; Chesser, D.G.; Ellingson, W.J.; Greenwood, L.J.; Porter, B.B.; Herway, S.T.; Winder, W.W. Endurance Training Increases Skeletal Muscle LKB1 and PGC-1alpha Protein Abundance: Effects of Time and Intensity. Am. J. Physiol. Endocrinol. Metab. 2005, 289, E960-E968. [CrossRef]

126. Terada, S.; Goto, M.; Kato, M.; Kawanaka, K.; Shimokawa, T.; Tabata, I. Effects of Low-Intensity Prolonged Exercise on PGC-1 mRNA Expression in Rat Epitrochlearis Muscle. Biochem. Biophys. Res. Commun. 2002, 296, 350-354. [CrossRef]

127. Wan, Z.; Root-McCaig, J.; Castellani, L.; Kemp, B.E.; Steinberg, G.R.; Wright, D.C. Evidence for the Role of AMPK in Regulating PGC-1 Alpha Expression and Mitochondrial Proteins in Mouse Epididymal Adipose Tissue. Obesity 2014, 22, 730-738. [CrossRef]

128. Yan, M.; Audet-Walsh, É.; Manteghi, S.; Dufour, C.R.; Walker, B.; Baba, M.; St-Pierre, J.; Giguère, V.; Pause, A. Chronic AMPK Activation via Loss of FLCN Induces Functional Beige Adipose Tissue Through PGC-1 $\alpha /$ ERR $\alpha$. Genes Dev. 2016, 30, 1034-1046. [CrossRef]

129. Muoio, D.M.; Way, J.M.; Tanner, C.J.; Winegar, D.A.; Kliewer, S.A.; Houmard, J.A.; Kraus, W.E.; Dohm, G.L. Peroxisome Proliferator-Activated Receptor-Alpha Regulates Fatty Acid Utilization in Primary Human Skeletal Muscle Cells. Diabetes 2002, 51, 901-909. [CrossRef]

130. Lin, J.; Handschin, C.; Spiegelman, B.M. Metabolic Control through the PGC-1 Family of Transcription Coactivators. Cell Metab. 2005, 1, 361-370. [CrossRef]

131. Jäger, S.; Handschin, C.; St-Pierre, J.; Spiegelman, B.M. AMP-activated Protein Kinase (AMPK) Action in Skeletal Muscle via Direct Phosphorylation of PGC-1alpha. Proc. Natl. Acad. Sci. USA 2007, 104, 12017-12022. [CrossRef]

132. Huang, M.; Zhou, C.; Zhang, Y.; Zhang, X.; Xu, W.; Lin, J.; Wang, P. Salvianolic Acid B Ameliorates Hyperglycemia and Dyslipidemia in db/db Mice Through the AMPK Pathway. Cell Physiol. Biochem. 2016, 40, 933-943. [CrossRef] [PubMed]

133. Cantó, C.; Auwerx, J. AMP-activated Protein Kinase and Its Downstream Transcriptional Pathways. Cell Mol. Life Sci. 2010, 67, 3407-3423. [CrossRef] [PubMed]

134. Tang, T.; Song, J.; Li, J.; Wang, H.; Zhang, Y.; Suo, H. Synbiotic Consisting of Lactobacillus Plantarum S58 and Hull-Less Barley $\beta$-glucan Ameliorates Lipid Accumulation in Mice Fed With a High-Fat Diet by Activating AMPK Signaling and Modulating the Gut Microbiota. Carbohydr. Polym. 2020, 243, 116398. [CrossRef] [PubMed]

135. Guo, L.; Kang, J.S.; Park, Y.H.; Je, B.; Lee, Y.; Kang, N.; Park, S.; Hwang, D.Y.; Choi, Y.W. S-petasin Inhibits Lipid Accumulation in Oleic Acid-Induced HepG2 Cells Through Activation of the AMPK Signaling Pathway. Food Funct. 2020, 11, 5664-5673. [CrossRef] [PubMed]

136. Carmen, G.; Víctor, S. Signalling Mechanisms Regulating Lipolysis. Cell Signal. 2006, 18, 401-408. [CrossRef]

137. Jocken, J.W.E.; Hernández, M.A.G.; Hoebers, N.T.H.; Beek, C.M.; Essers, Y.P.G.; Blaak, E.E.; Canfora, E.E. Short-Chain Fatty Acids Differentially Affect Intracellular Lipolysis in a Human White Adipocyte Model. Front. Endocrinol. 2018, 8, 372. [CrossRef]

138. Yap, F.; Craddock, L.; Yang, J. Mechanism of AMPK Suppression of LXR-dependent Srebp-1c Transcription. Int. J. Biol. Sci. 2011, 7, 645-650. [CrossRef]

139. Besten, G.; Bleeker, A.; Gerding, A.; Eunenet, K.; Havinga, R.; Dijk, T.; Oosterveer, M.; Jonker, J.; Groen, A.; Reijngoud, D.; et al. Short-Chain Fatty Acids Protect Against High-Fat Diet-Induced Obesity via a PPAR $\gamma$-Dependent Switch From Lipogenesis to Fat Oxidation. Diabetes 2015, 64, 2398-2408. [CrossRef]

(C) 2020 by the authors. Licensee MDPI, Basel, Switzerland. This article is an open access article distributed under the terms and conditions of the Creative Commons Attribution (CC BY) license (http://creativecommons.org/licenses/by/4.0/). 